\title{
PENDIDIKAN KESEHATAN PENTINGNYA KUNJUNGAN NIFAS KF- 3 DI KAMPUNG DAPUR 6 KELURAHAN SEMBULANG KECAMATAN GALANG KOTA BATAM TAHUN 2020
}

\author{
Septi Maisyaroh Ulina Panggabean ${ }^{1}$, Siti Erika ${ }^{2}$, Akmalia Purnomo ${ }^{3}$ \\ ${ }^{1,2,3,)}$ Program Studi D- III Kebidanan, Sekolah Tinggi Ilmu Kesehatan Awal Bros Batam \\ Email korespondensi: septi.panggabean190989@gmail.com
}

\begin{abstract}
Abstrak
Diperkirakan 60\% kematian ibu akibat kehamilan terjadi setelah persalinan dan 50\% kematian masa nifas terjadi dalam 24 jam pertama (Ambarwati, 2015). Penyebab langsung yang berkaitan dengan kematian ibu adalah komplikasi pada kehamilan, persalinan dan nifas tidak ditangani dengan baik dan tepat waktu. Kematian ibu pada masa nifas biasanya disebabkan oleh infeksi nifas (10\%), ini terjadi karena kurangnya perawatan luka, perdarahan (42\%) akibat robekan jalan lahir, sisa plasenta dan atonia uteri, eklamsia (13\%) dan komplikasi masa nifas (11\%) (Suyono, 2015). Asuhan masa nifas diperlukan karena merupakan masa kritis baik ibu maupun bayinya. Keberhasilan upaya kesehatan ibu nifas di ukur melalui indikator cakupan pelayanan kesehatan ibu nifas (cakupan kf-3). Indikator ini menilai kemampuan Negara dalam menyediakan pelayanan kesehatan ibu nifas yang berkualitas dalam standar. (Nugroho, 2017).

Berdasarkan data sekunder yang diperoleh dari Dinas Kesehatan Kota Batam pada tahun 2019 kunjungan nifas urutan terendah kedua terdapat pada Puskesmas Galang dengan cakupan kunjungan nifas 1 sebanyak 76,9\%. kunjungan 2 sebanyak $64.2 \%$ dan kunjungan nifas 3 sebanyak 52,8\%. Dalam pelaksanaan masa nifas sangat jarang terwujud dikarenakan oleh beberapa faktor diantaranya yaitu rendahnya pengetahuan ibu nifas tentang pendidikan kesehatan.

Kunjungan masa nifas sangat diperlukan untuk mendeteksi dini komplikasi pada masa nifas, komplikasi pada masa nifas. Terdapat beberapa komplikasi pada masa nifas yang dapat menyumbangkan AKI, diantaranya: perdarahan pascasalin kala III merupakan penyebab utama kematian ibu. Meningkatkan pengetahuan tentang pencegahan komplikasi nifas dengan memberikan konseling pada saat sebelum pulang, saat setelah melahirkan, pengadaan penyuluhan baik secara individu maupun kelompok yang bekerja sama dengan tenaga instansi kesehatan setempat.
\end{abstract}

Kata kunci: Pencegahan Komplikasi Nifas, Pengetahuan, Sikap, Perilaku 


\begin{abstract}
It is estimated that $60 \%$ of maternal deaths due to pregnancy occur after delivery and $50 \%$ of postpartum deaths occur within the first 24 hours (Ambarwati, 2015). The direct causes related to maternal mortality are complications in pregnancy, childbirth and the puerperium which are not handled properly and on time. Maternal mortality during the puerperium is usually caused by puerperal infection (10\%), this occurs due to inadequate wound care, bleeding (42\%) due to tearing of the birth canal, remaining placenta and uterine atony, eclampsia (13\%) and complications of the puerperium (11\%). ) (Suyono, 2015). Postpartum care is needed because it is a critical period for both mother and baby. The success of postpartum maternal health efforts is measured through indicators of postpartum health care coverage ( $k f-3$ coverage). This indicator assesses the State's ability to provide standard quality postpartum maternal health services. (Nugroho, 2017).

Based on secondary data obtained from the Batam City Health Office in 2019, the second lowest postpartum visit was at Galang Health Center with a coverage of $76.9 \%$ postpartum visits. the second visit was $64.2 \%$ and the $3 r d$ postpartum visit was $52.8 \%$. In the implementation of the postpartum period, it is rarely realized due to several factors, including the low knowledge of postpartum mothers about health education.

Postpartum visits are needed to detect early complications during the puerperium, complications during the puerperium. There are several complications during the puerperium that can contribute to AKI, including:

Stage III postpartum hemorrhage is the main cause of maternal death. Increase knowledge about the prevention of postpartum complications by providing counseling at the time before going home, at the time of delivery, provision of counseling both individually and in groups in collaboration with local health authorities
\end{abstract}

Keywords: knowledge, Acetic Acid Visual Infection 


\section{PENDAHULUAN}

Target global MDGs (Development Goals) menurunkan angka kematian ibu (AKI) menjadi 102 per 100.000 kelahiran hidup pada tahun 2017. AKI di Indonesia pada Tahun 2016 sebesar 305 per 100 ribu kelahiran hidup1, AKI di Provinsi Jawa Tengah pada tahun 2017 sebesar 127.96 per 100 ribu kelahiran hidup, dengan jumlah kematian ibu terjadi pada masa nifas sebanyak 45,90\%.

Dari data diatas menunjukkan angka kematian ibu di Kota Batam masih jauh dari target SDGs. Hal ini seperti disampaikan oleh WHO bahwa masalah bisa terjadi pada masa nifas yang jika tidak ditangani dengan segera dan efektif dapat menyebabkan masalah kesehatan bahkan kematian bagi ibu maupun bayinya, namun perawatan nifas sering diabaikan padahal secara fakta mayoritas kematian ibu dan kecacatan terjadi pada masa nifas dan kematian bayi juga tinggi. Perhatian untuk meningkatkan kesehatan ibu pada masa nifas antara lain dengan pelaksanaan pelayanan ibu nifas yaitu pelayanan kesehatan yang diberikan kepada ibu mulai dari 6 jam sampai dengan 42 hari setelah melahirkan sesuai standar oleh tenaga kesehatan. Pelayanan nifas minimal 3 (tiga) kali yaitu kunjungan nifas yang pertama (KF1) pada waktu 6 jam setelah melahirkan sampai 3 hari, kunjungan nifas kedua (KF2) dalam waktu 2 (dua) minggu setelah melahirkan (8-14 hari) dan kunjungan nifas ketiga (KF3) dalam waktu 6 (enam) minggu post partum (36-42 hari) 10 .

Pelayanan kesehatan bagi ibu dan bayi dalam masa nifas dilakukan untuk membantu proses ibu dan bayi dalam proses pemulihan, penjelasan mengenai perawatan pada tali pusat, deteksi dini kejadian abnormal masa nifas, penanganan dan rujukan terhadap kejadian tak diinginkan yang bisa terjadi, kesehatan secara umum, kebersihan individu, kebutuhan gizi, $\quad$ perawatan bayi, pemberian ASI, imunisasi dan KB. Mutu pelayanan dasar yang harus diberikan pemerintah kepada masyarakat dapat dilihat dari capaian SPM yang merupakan pencapaian target sebagai hasil kinerja pemerintah maka harus $100 \%$ setiap tahunnya.

Untuk dapat melaksanakan pelayanan nifas yang bermutu dan berkualitas, maka perlu melakukan peningkatan standar menjaga mutu sebagai acuan dalam memperbaiki dan meningkatkan kinerja pelayanan nifas oleh bidan. Kinerja adalah hasil kerja secara kualitas dan kuantitas yang dicapai oleh seseorang dalam melaksanakan tugas sesuai tanggung jawab yang diberikan.Berdasarkan teori Gibson bahwa ada tiga variabel yang dapat mempengaruhi perilaku dan kinerja yaitu variabel individu terdiri dari kemampuan dan keterampilan, latar belakang serta demografi, variabel psikologis yang terdiri dari persepsi, sikap, kepribadian, belajar dan motivasi, serta variabel organisasi yang terdiri SDM, kepemimpinan, imbalan, struktur, supervisi, beban kerja dan desain pekerjaan. Output yang diharapkan dari setiap perilaku adalah prestasi dalam melaksanakan pekerjaan sehingga pelayanan yang diberikan bermutu.

Bidan dalam pelaksanaan pelayanan nifas belum sesuai Standar Operasional Prosedur (SOP), dan semua bidan belum lengkap dalam memberikan pelayanan nifas yang terdiri dari identifikasi dan analisis masalah meliputi pengkajian data subyektif dan obyektif, perumusan diagnosa sudah dilaksanakan, penyusunan rencana belum maksimal hanya berdasarkan keluhan pasien, pelaksanaan tindakan sudah dilaksanakan berdasarkan keluhan, belum semua bidan melakukan evaluasi, konseling tentang masa nifas hanya diberikan secara umum. Hal ini tidak sesuai dengan hasil penelitian Roberts dan Prevost bahwa mutu layanan kesehatanadalah terkait dimensi kesesuaian pelayanan kesehatan yang dilaksanakan dengan perkembangan IPTEK serta otonomi profesi dalam menyelenggarakan layanan kesehatan sesuai kebutuhan pasien. Belum semua bidan melakukan pencatatan di register pemeriksaan ibu nifas maupun 
rekam medik, juga dicatat di buku KIA pasien, hal ini tidak sesuai dengan manajemen kebidanan yang harus melakukan dokumentasi setelah melakukan pelayanan kebidanan.

Tidak ada dukungan dana transportasi kunjungan nifas ke rumah pasien, belum ada pembinaan atau pengawasan yang intensif dari bidan koordinator, kepala puskesmas maupun Dinas Kesehatan terhadap pelaksanaan pelayanan nifas hal ini diketahui ada bidan desa yang tidak mengetahui harus melaksanakan kunjungan rumah ke ibu nifas di wilayahnya. Bidan ada yang merangkap sebagai bendahara dan pemegang program, hal ini akan menambah beban kerja pegawai bersangkutan yang berpengaruh pada mutu pelayanan kesehatan karena mutu pelayanan kesehatan dipengaruhi oleh jenis, jumlah dan kualifikasi tenaga pelaksana. Tujuan pengabmas ini untuk memberikan pendidikan mengetahui tentang mutu pelayanan nifas tiga (KF3) dan faktor-faktor yang mempengaruhi mutu pelayanan nifas oleh bidan di puskesmas di wilayah . Kampung Dapur 6 Kelurahan Sembulang Kecamatan Galang Kota Batam

\section{METODE}

Kegiatan PKM ini dilakukan dengan metode pendidikan kesehatan masyarakat dalam bentuk penyuluhan dan. Pelaksanaan dalam kegiatan ini adalah memberikan materi dengan ceramah, diskusi dan Tanya jawab serta pemeriksaan kesehatan. Media yang digunakan adalah power point menggunakan laptop dan in-focus serta pemberian leaflet dilanjutkan dengan pemeriksaan KF3 langsung dibantu oleh mitra kegiatan yang berasal dari puskesmas setempat. Peserta juga diberikan pre dan post test untuk mengukur pengetahuan dan evaluasi keberhasilan dalam pemberian pendidikan kesehatan kepada masyarakat. Lokasi kegiatan ini dilaksanakan di Kampung Dapur 6 Kelurahan Sembulang Kecamatan Galang Kota Batam, dengan jumlah peserta ibu Nifas.

Tahap pelaksanaan dari kegiatan ini dimulai dari pengenalan fasilitator dan tujuan kegiatan, pretest, pemberian materi pijat bayi yang meliputi mengenai apa itu pijat bayi, langkah pelaksanaan, dan manfaatnya, demonstrasi, tanya jawab dan post test, lalu re-demonstrasi dengan pendampingan fasilitator. Evaluasi hasil dari kegiatan ini adalah dilakukan dengan memberikan post test dan melihat langsung kemampuan peserta dalam melakukan pijat bayi.

\section{DOKUMENTASI KEGIATAN}

Gambar 1. Kegiatan Pendataan dan Pre Test Sebelum Dimulai Pendidikan Kesehatan

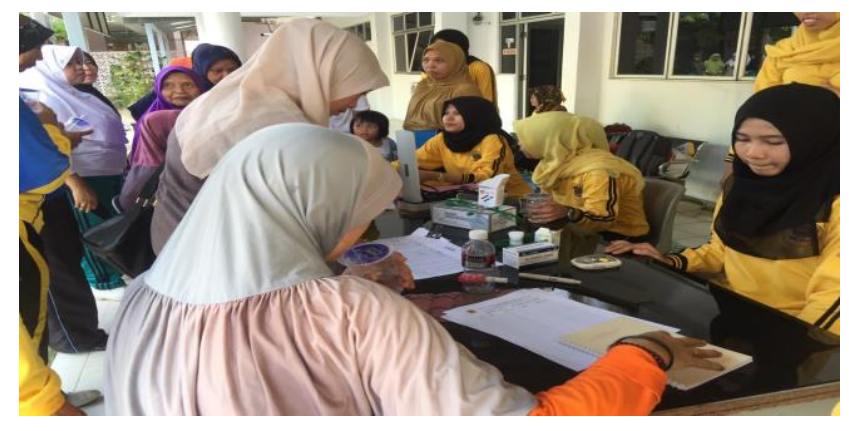


Gambar 2. Kegiatan Pendidikan Kesehatan

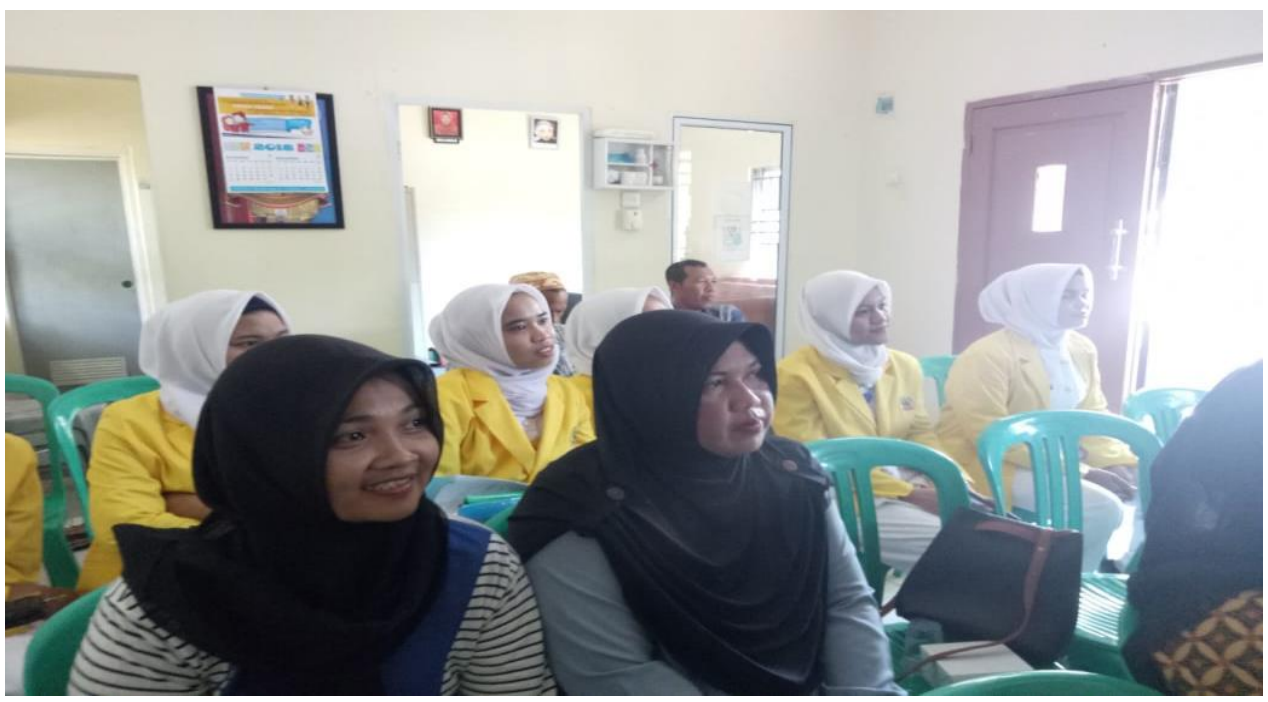

\section{HASIL DAN PEMBAHASAN}

\section{Hasil}

1. Tahap persiapan

Melakukan rapat koordinasi dengan tim yang dilakukan pada tanggal 23 Maret 2020 dari hasil rapat disepakati untuk melakukan studi pendahuluan dengan instansi terkait yaitu: pihak Dinas Kesehatan, Puskesmas Bulang, kader puskesmas. Setelah studi pendahuluan lalu dilakukan rapat koordinasi untuk disepakati persiapan pelatihan dengan persiapan materi mengenai pijat bayi. Kegiatan ini dibantu oleh Puskesmas dan para kader untuk menyebarkan informasi.

2. Tahap implementasi

Pelaksanaan kegiatan ini dilaksanakan pada Bulan Maret Tahun 2020, dengan melibatkan 2 orang dosen dan dua orang mahasiswa. Kegiatan ini diikuti oleh 12 ibu-ibu Nifas. Pada saat penyampaian materi peserta mampu mengulang kembali materi yang disampaikan, peserta aktif dalam diskusi dan tanya jawab, juga mampu melakukan re-demonstrasi.

\section{Tahap Evaluasi}

Evaluasi hasil dari kegiatan ini adalah peserta dapat memahami materi dan bersedia melakuakan kunjungan KF3 dengan baik, dari hasil post test didapatkan peserta yang memiliki pengetahuan baik sebanyak sepuluh orang atau 83,3\%. Sebagian besar peserta berusia 25-34 tahun, dengan pendidikan terakhir di SMA, dengan seluruh peserta merupakan ibu rumah tangga. Peserta dan para kader antusias dalam melakukan kegiatan ini.

\section{PEMBAHASAN}

Pada kegiatan ini peserta pelatihan adalah ibu-ibu Nifas yang ada di Kelurahan Tanjung Riau Sekupang sebanyak 12 orang. Kelompok umur peserta terbanyak pada usia 25-34 tahun sebanyak 7 orang, jika dilihat dari usia peserta, berada dalam perkembangan dewasa muda, sehingga mempengaruhi peningkatan pengetahuan dan keterampilan pada peserta pelatihan, Hasil ini sejalan dengan penelitian Akhenan dan Puspitasari (2011) dimana responden dengan usia 20 tahun paling melaksanakan PNC yang 
menyatakan bahwa usia mempunyai kaitan erat dengan kemampuan memahami dan keterampilan melaksanakan tugas maupun kedewasaan psikologis.

Pengukuran keberhasilan pendidikan kesehatan kunjungan Nifas (KF3) menggunakan kuesioner dan lembar observasi yang diukur sebelum dan sesudah pelatihan. Langkah- langkah dalam pelatihan dilakukan secara terstruktur. Diawali dengan memberikan pendidikan kesehatan dengan modul materi kunjungan Nifas dan power point, langkah selanjutnya adalah melakukan demonstrasi dengan audiovisual dan demonstrasi langsung, kemudian dengan melakukan pendampingan ibu ibu peserta pelatihan dalam melakukan pijat bayi. Metode demontrasi adalah metode penyajian pembelajaran dengan memperagakan tentang suatu proses, atau situasi tertentu baik sebenarnya atau hanya sekedar tiruan (Marni, 2018).

Pengetahuan kunjungan Nifas yang diberikan meliputi tentang pengertian, manfaat kunjungan nifas, kapan waktu yang tepat, perhatian khusus saat melakukan pijat dan persiapan pemijatan bayi yang disertai dengan gambar. Peningkatan pengetahuan dan keterampilan ibu ibu peserta pelatihan dalam melakukan kunjungan nifas pada kegiatan ini dapat dipengaruhi oleh beberapa faktor antara lain; pelatihan dilakukan pada kelompok kecil yaitu berjumlah 12 orang dan jumlah fasilitator sebanyak dua orang, dan evaluasi dilaksanakan langsung. Meskipun peningkatan pengetahuan dan kunjungan Nifas ibu sebagian besar adalah baik, namun masih ada beberapa ibu yang masih ragu melakukan kunjungan. Hal ini dapat disebabkan pengetahuan ibu sebelumnya, dan usia ibu yang terlalu muda sehingga belum dapat memahami materi dengan baik.

\section{SIMPULAN}

Berdasarkan hasil kegiatan PKM pelatihan pendidikan kesehatan terhadap ibu Nifas di Kampung Dapur 6 Kelurahan Sembulang Kecamatan Galang Kota Batam dapat disimpulkan bahwa terdapat peningkatan pengetahuan ibu setelah diberikan pendidikan kesehatan dengan kategori baik 83,3\%.

\section{SARAN}

Saran dalam kegiatan PKM ini adalah untuk lebih berkoordinasi dengan kader-kader yang ada melibatkan lebih banyak wilayah, dengan harapan peserta yang terkumpul lebih banyak, dan evaluasi dilakukan secara bertahap tidak dalam suatu waktu.

\section{UCAPAN TERIMA KASIH}

Tim penulis mengucapkan terima kasih kepada semua pihak yang telah membantu kelancaran pelaksanaan Pengabdian Kepada Masyarakat ini di Kampung Dapur 6 Kelurahan Sembulang Kecamatan Galang Kota Batam, kepada segenap civitas akademika STIKes Awal Bros Batam dan Yayasan Bangun Bangsa.

\section{DAFTAR PUSTAKA}

Kementerian Kesehatan RI. Mother Day Situasi Kesehatan Ibu. Kementerian Kesehatan RI: Jakarta, 2014. 2 Kementerian Kesehatan RI. Profil Kesehatan Indonesia Tahun 2015 Kesehatan RI: Jakarta, 2016 Ambarwati (2015). Prosedur Penelitian Suatu Pendekatan dan pelayanan kesehatan

Dinas Kesehatan Kota Batam (2019). Profil Kesehatan Kota Batam

Kemenkes RI (2016) . Profil kesehatan Indonesia

Nugroho (2017). Obstetric. Penerbit Nuha Medika Yogyakarta

Suyono (2015). Patologi kebidanan. Penerbit Nuha Medika Yogyakarta

Lydia (2018). Analysis of Postpartum Complication Prevention Implementation at Working Area Paal V Society Health Center Jambi City in 2018: Scientia Journal,Vol.8,1 Mei 2019. 